\title{
Cosmopolitanism - an alternative for Global Governance?
}

\author{
A new model for a new international conflict line $e^{80}$
}

\section{Stefan Wallaschek}

Stefan W allaschek, 27, received his Bachelor of Arts in Political Science and Social Anthropology at the MartinLuther-University Halle-Wittenberg in 2011 and currently studies Political Science in the master program at the University of Bremen. He is writing his master thesis on 'cosmopolitanism in the public sphere". In September 2014 he will start his PhD at the Bremen International Graduate School for Social Sciences (BIGSSS). His current research interests are modern political theory, migration politics, political communication and qualitative methods.

\begin{abstract}
In the last decades Global Governance was one of the most used and contested terms in International Relations. Many researchers have shown that the concept is overstretched and they call for alternatives. Can Cosmopolitanism as a "new" international political theory be an alternative? I will propose a new theoretical model which can be used to analyze cosmopolitanism empirically. Drawing on both normative and empirical research on cosmopolitanism I demonstrate the necessary combination of both. I formulate a two-axesmodel which is based on norms and conflicts. Such a theoretically based and empirically applicable model can be used to analyze different (claims of) actors in relation to a (cosmopolitan) position. In addition the model gives researchers the opportunity to scrutinize the relevance of international norms on different levels and thus offers a possible visualization of the interconnection between global arrangements and local activities. Therefore the model presents an alternative to Global Governance.
\end{abstract}

Keywords: Communitarism; Cosmopolitanism; Global Governance; International Political Theory; Particularism; Politics of Space.

\footnotetext{
${ }^{80} \mathrm{I}$ am grateful to the participants of the IAPSS World Congress for their comments as well as Janosik Herder, Martin Nonhoff and Sandra Reinecke for their notes of earlier drafts of this article.
} 


\section{Introduction}

Governance is both en vogue and an 'empty signifier' as Claus Offe (2009) provocatively states. It seems that Governance research has been the 'new' paradigm of political science and especially in International Relations ${ }^{81}$ the term global governance has been omnipresent in the last two decades. Surprisingly, there is no concrete definition of governance. Moreover, it seems that every researcher has its own interpretation of what governance means and in academic handbooks and anthologies on governance a big variety of definitions and usages of this concept exist (e. g. Schuppert and Zürn 2008; Enderlein et al. 2010; Levi-Faur 2012). Consequently, Schuppert describes governance as an "accepted ambiguous term" in academics (Schuppert 2008) which is an interesting evaluation of the state of the art, but from an analytic perspective it is not very helpful.

Apart from the general and mostly uncritical usage of this term, critics try to examine the deficits and problems of the 'catch-all-term' global governance. In the last years a critical debate of global governance concepts has been established. While some researchers try to improve the global governance concept and distinguish between the analytic, the normative and the public use of the global governance term (Dingwerth and Pattberg 2006), other academics criticize (global) governance itself and try to reframe the term in a more emancipated and critical way (Brand 2005; 2007).

Instead of reframing terminological debates on governance, my main question is: Can a cosmopolitan approach be an alternative to global governance? In order to answer this question, I introduce the cosmopolitan approach by Seyla Benhabib, but I will go further and develop a cosmopolitan model. I will argue that a cosmopolitan approach has two advantages in comparison to a critical governance perspective. Firstly, cosmopolitanism is based on international norms such as freedom or justice. It has a clear theoretical base and furthermore an obvious goal - a cosmopolitan order - which are not existent in either of the other approaches - critical and noncritical governance. Secondly, a cosmopolitan approach is not bound to an institutional and efficient-oriented perspective, because cosmopolitanism and democracy cannot be divided. A cosmopolitan order has to be democratic ${ }^{82}$ and cosmopolitan thinkers argue for a broad participation of the people and interest groups such as NGO's as well as the involvement of nation-states in new international treaties. While governance approaches are mostly focused on changing structures, a cosmopolitan approach recognizes the actors in a changing structure. The

\footnotetext{
81 By using initial capitals for 'International Relations' I refer to the discipline and by using regular letters for 'international relations' I mean the topic of the discipline.

${ }^{82}$ It is not the other way around which means that a democracy does not have to be cosmopolitan.
} 
different actors and their different localizations have to be recognized profoundly for a cosmopolitan model. Moreover, such a model has to clarify what the opposite of cosmopolitanism is ${ }^{83}$ and, thus, I will argue for particularism as the opposite of cosmopolitanism.

I will structure my paper as follows. In the next chapter I review the existing critics of the governance literature and show that their criticism is not sufficient. I introduce the cosmopolitanism by Seyla Benhabib and describe her main theoretical ideas in chapter three. Based on her approach and findings from the empirical cosmopolitan studies I develop the model and argue for a combination of normative and empirical research in the next part of my paper. In the last chapter I summarize and reflect my work and I argue for the relevance of a cosmopolitan view in governance research.

\section{Global Governance and its critics}

\subsection{Defining (global) governance}

The origins of the governance literature are the changing relations of polity, policy and politics as well as complex interconnections of state, economy and society. A functional and territorial distinction of state and market sphere is difficult and thus, as Arthur Benz states (2004, 13-15) the term 'governance' can help to understand and fix its own changes. Edgar Grande defines five aspects of governance: a non-hierarchical structure for the production of public goods, a criticism of the state, multiple interdependence between actors, policies and levels of social action, an increased complexity and the need for cooperation and coordination (Grande 2012, 566-567).

In International Relations the term 'global governance' can be seen as a double shift of the established perspective: from international to global politics and from government-oriented politics to governance as a broad technique to manage problems (Kacowicz 2012, 688). Furthermore global governance describes firstly the absence of a (global) sovereign with a clear identifiable domination structure, secondly the interconnection of coercion and cooperation in international relations and thirdly the continuous transformation of structures and processes (Benz 2004, 16-17).

The emergence of new global actors such as transnational social movements, private international networks or non-state spheres of authority goes hand in hand with the

\footnotetext{
${ }^{83}$ It is interesting to note that both the governance and the cosmopolitan approaches mostly have not theorized the opposite of its assumption: If it is not cosmopolitan, what is it? If it is not a (global) governance structure, what is it (for the governance-part see Dingwerth and Pattberg 2006, 389-393; Offe 2009, 551)? I will come back to this point in chapter four.
} 
transformation of structures. Dingwerth and Pattberg $(2006,388)$ describe this pluralist and nonstate-centrist perspective as strengths of global governance approaches. The concept of governance is nevertheless more focused on structures than on actors (Risse 2008; Offe 2009). Hence, there are criticisms on the strong institutional focus, the missing recognition of social and economic circumstances and the absent ethical foundation of global governance (Kacowicz 2012, 695), I will draw more attention to these critics.

\subsection{Criticisms of Global Governance}

In his articles Ulrich Brand points out that the research on global governance often falls together with an implicit normative understanding of good governance. The terminological relevance in the public as well as in social sciences supports a meaning which relates to an efficient solving of (world) problems ${ }^{84}$. A critical governance approach, which tries to investigate an alternative global structure and to show the socio-economic contradictions of the "postfordist politics", is not wanted (Brand 2005, 165-167; Brand 2011a). Thus, so Brand in another article $(2007,40)$, the mainstream research on global governance justifies the existing global order and it can be added that this mainstream has "a tendentious blindness for questions of power, distribution, and conflict" (Offe 2009, 558; also Grande 2012, 584).

Although the state is not in the academic focus anymore, Brand criticizes that the regulative ability of the state is further on the implicit normative goal in governance approaches. The western liberal state is not only a neutral instance, but also the exclusive political order for an efficient regulation and has the capacity to act in a global governance structure (Brand 2007, 35-37). Otherwise, as Offe (2009, 555-556) states, governance can be seen as a new rhetoric framework to justify the reduction of state services. Horizontal cooperation and support through outsourcing governance structures seems to be more effective than a hierarchical bureaucratic state structure. Moreover, the broader inclusion of non-state actors can introduce societal selforganization and thus governance is the result of the limited state capacity in times of globalization and liberalization. The political result would be a less democratic structure.

Another criticism is that the term 'global' in global governance is far away from really being global. Dieter Senghaas scrutinizes the research on global governance and shows the bias between a highly connected and regulated OECD-world and 'the rest of the world' including approximately 80 per cent of all human beings which are not integrated in the thick governance

\footnotetext{
${ }^{84}$ To solve problems is the ubiquitous goal of global governance, but the academic discourse on governance misses three aspects: Firstly if cooperation through governance is the major global acting or the minor acting, secondly if every cooperation leads to problem-solving or are these the well-researched exceptions and thirdly the failure of governance is not addressed and discussed (Dingwerth and Pattberg 2006, 392-393).
} 
structure. This theoretical and empirical pitfall is hardly recognized in the literature on global governance (Senghaas 2003).

Finally, global governance is a form of regulation and order on a global and complex level and it seems that the crucial aim is not to make a political decision but to manage a problem in the right manner. In addition, with the focus on constantly changing structures, it seems that any acting in a global governance structure is a problem-solving acting without political or ideological convictions. Instead of political ideologies, conflict and legitimacy, cooperation, effectiveness and regulation seem to be the ruling aspects of global governance. Moreover, the assumption that every actor in the global governance structure theoretically has the same rank and impact on political decision-making (Dingwerth and Pattberg 2006, 381) is naïve and ignores the existing power relations.

The criticisms of global governance are manifold and therefore, the question is, are there alternatives to it and how do they look (similar Grande 2012, 587)? In the next section, I present cosmopolitanism as a possible alternative, describe the main aspects of it and show the advantages of a cosmopolitan perspective.

\section{Federal cosmopolitanism by S. Benhabib}

Cosmopolitanism has been one of the most important international political theories in the last years (Delanty 2012). The Kantian version of cosmopolitanism is the most prominent one and it has been combined with ideas of deliberative democracy (Held 1997; Habermas 1998b; Archibugi 2003).

\subsection{Benhabib and discourse theory}

Seyla Benhabib has further developed this approach and apart from using Kant's idea of hospitality, she uses Hannah Arendt's thought on "the right, to have rights" to examine a new cosmopolitan approach (Benhabib 2006a; Benhabib 2009; Benhabib 2011a). Benhabib’s federal cosmopolitanism does not have an institutional focus or will propose a new institutional arrangement such as David Held does (1997). Instead her approach is norm-based. She demonstrates that the Universal Declaration of Human Rights (1948) inaugurates a new era of international law in which numerous international agreements and regimes on the rights of women, children or refugees emphasize individuals - and their rights - as its objects.

Since international norms such as justice or self-determination are the base for every international agreement, Benhabib asks how these norms can be negotiated and justified. She uses discourse theory and ethics by Jürgen Habermas (1998a), but she advances two aspects of it. 
Firstly, Benhabib claims that every public discourse has to be open for everyone who is affected by the issue of this discourse. Thus, the limits of public discourse have to be questioned ${ }^{85}$. She claims that the discourse participants have to reflect the discourse limitations. The participation in a discourse is her second point. Benhabib states that every discourse participant has to recognize the others as equal with the same right to argue. Furthermore, the arguments of the others have to be recognized too and the inner-discursive dispute has to be structured as reciprocal dialogue. In conclusion, Benhabib tries to handle the problems of the deliberative discourse theory through a general openness of the discourse for all affected individuals and an equal participation and reciprocal structure in the discourse (Benhabib 2009, 24-30). The result is that in every discourse the discourse itself, its normative groundings and its discourse principles should be considered.

\subsection{From national to international to cosmopolitan law}

As mentioned above, Benhabib sees a transformation of law: Starting from a national context of law in the treaty of Westphalia in 1648 which guarantees every state the unlimited sovereignty of its territory to the first international laws at the beginning of the $20^{\text {th }}$ century. Benhabib's final stage is the emerging cosmopolitan law at the beginning of the $21^{\text {st }}$ century. The foundations for this emergence are manifold agreements and treaties such as the Universal Declaration of Human Rights or the Geneva Convention relating to the Status of Refugees of 1951 (and its protocol in 1967). While in international law the main content is the regulation of national interests and national cooperation, the content of these new treaties are the rights, the protection and the freedom of individuals and the fact that nation-states have to guarantee these norms through their subscription. Moreover, apart from the nation-states, the recognition of a plurality of international actors such as NGO's, transnational social movements and individuals is another sign that the law is in transformation; individuals have among others the right to initiate proceedings against states if they violate human rights (Benhabib 2006a). The transformation from a state-centric to a cosmopolitan perspective ${ }^{86}$ is interconnected with the emphasis on human rights as fundamental rights for every human being; independent from their affiliation and nationality. She explains this with Hannah Arendt's account on "the right to have rights”: "„I propose that the ,right to have rights“ needs to be understood more broadly as the

\footnotetext{
${ }^{85}$ For example she exposes the problem of public agency for children or disabled people who are mostly not part of such a discourse because of their age or 'unnormal' physicial and/or psychic conditions.

${ }^{86}$ Important to note is that Benhabib is against the abolition of nation-states or the idea of a world-state. She argues for recognizing the multiplicity of actors on the international level by focusing on the interconnections between human rights, state-centric treatments and non-state actors. Therefore Benhabib argues for a cosmopolitan "republican federalism" (Benhabib 2011c, 112-116).
} 
claim of each human person to be recognized and to be protected as a legal personality by the world community“ (Benhabib 2011b, 9).

Apart from this fundamental consideration Benhabib has the idea that every (international) norm has to be justified through a discourse; it does not matter if this norm still exists or will be introduced by a new treaty. Only a public discourse legitimates an international norm because the people affected by this norm are concurrently the authors of it (through the participation in the discourse). Since the people can participate in such a discourse, they are involved in the pre-decision-making process and can argue for or against the norm, the process itself is democratic. Benhabib calls such a process a "democratic iteration" (Benhabib 2006c, 4751; Benhabib 2009, 174-179). The iteration symbolizes that a term does not have an original and constant meaning, but is transformed by every usage in different contexts. Therefore, democratic iterations "are linguistic, legal, cultural, and political repetitions-in-transformation, invocations that also are revocations. They not only change established understandings but also transform what passes as the valid or established view of an authoritative precedent" (Benhabib 2006c, 48).

In contrast to the governance paradigm, Benhabib's cosmopolitanism has a strong focus on democratic processes and participation of the people; also on the international respectively cosmopolitan level. Moreover, she reveals her normative assumptions and goals and does not argue for democratic legitimacy through efficiency and "top-down"-regulation. Benhabib involves the people in two ways: As objects by binding them to international treaties and human rights and as subjects as authors of cosmopolitan norms which are discussed within the above mentioned public discourses. With these claims, she does not only focus on the global, but also the local and national level for the grounding of cosmopolitan norms.

Benhabib scrutinizes her theoretical idea of the interconnection of the local, the national and the global in cosmopolitan norms by examining the head scarf affair in France and Germany and the debate on the definition of German citizenship (Benhabib 2009, 179-202). The problem with her explorative approach is that Benhabib grants the interconnection and the relevance of cosmopolitan norms. It is not clear if the participants of the discourse recognize the same transformation to cosmopolitan norms as Benhabib. Furthermore it seems that the localization of the actors as local or national is not very clear. The result is that Benhabib's theoretical ideas are interesting but her empirical findings are too narrow and superficial in its modus operandi. My aim is to fix this shortcoming by developing a social science model for measuring cosmopolitanism (and particularism as the opposite approach). In the next chapter I draw on the existing empirical research on cosmopolitanism, combine this with Benhabib and a new finding from the cleavage theory. At the end of the next chapter I will present my model. 


\section{A social science model for cosmopolitanism}

Most of the time normative and empirical cosmopolitan approaches do not engage with each other and, thus, they have hardly influenced each other, although empirical research on cosmopolitanism has significantly increased in the last years (Roudometof 2012). I will show that empirical as well as normative findings are well combinable and give fruitful insights for a model of cosmopolitanism.

\subsection{Empirical cosmopolitan research}

Only shortly after 2000 the broad empirical investigation of cosmopolitanism started and in the journal Current Sociology a debate on the measurement and operationalization of cosmopolitanism began.

Victor Roudometof has proposed a one-axis-model to measure cosmopolitanism. In his article he distinguishes between local and cosmopolitan whereas local and cosmopolitan are the end points on a continuum. A cosmopolitan attitude is "more (or less) ,open" towards the world" and thus "she or he is less (or more) 'bound' by territorial and cultural attachments" (Roudometof 2005, 122). This operationalization poses the questions: What are these territorial and cultural attachments and why can an individual only be a local or a cosmopolitan person? From Roudometof's perspective, the existence of a local cosmopolitan is not possible and therefore an individual has to detach its local affiliations and belongings to become a cosmopolitan.

Olofsson and Öhman criticize this approach and develop a two-axes-model. Their y-axis is the distinction of local and global while the $\mathrm{x}$-axis is constituted by the distinction of openness $^{87}$ and protectionism. They test their model with survey data from Sweden and distinguish four types: "local protectionists, open globals, global protectionists and open locals" (Olofsson and Öhman 2007, 886). Although their model constitutes a progress, their operationalization is inadequate. They use individual attitudes towards the liberalization (or protectionism) of the Swedish economy to measure openness or protectionism. Olofsson and Öhman mix up a liberal attitude towards an international economy with a cosmopolitan attitude which is based on human rights and the self-determination of the others; as I have shown in chapter three.

Finally, Florian Pichler summarizes the empirical cosmopolitan research and distinguishes between cosmopolitanism as a subjective and an objective concept (Pichler 2009, 710). He uses data from the European Value Survey (EVS), tests numerous hypotheses and

\footnotetext{
${ }^{87}$ Openness as crucial aspect of cosmopolitanism refers mostly to Ulf Hannerz (1990).
} 
combines objective aspects such as socio-economic factors (age, education level, income etc.) in the analysis. He examines that the objective concept is much better and grounds cosmopolitan attitudes in a more substantive way. For example only seven per cent of all people advocate the complete openness of national borders for immigrants and asked for the acceptance of different ethnic groups in their neighborhood. About 40 per cent say that they do not want Sinti and Roma in their neighborhood. A high education level and safe social status minimize the refusal of open borders and immigrants in the neighborhood (Pichler 2009, 717). Furthermore with a scale on how people feel affiliated with the local, national or global level, Pichler examines that the higher the affiliation to the local area, the higher is the affiliation to the global level and thus the identification as a cosmopolitan citizen (Pichler 2009, 721) ${ }^{88}$.

\subsection{Developing the cosmopolitan model}

Since local and cosmopolitan affiliations do not exclude each other, the theoretical opposite of cosmopolitanism and the concrete relation of the localization of actors have to be investigated. From this result I derive the y-axis as a continuum from local to global. However, global is not equal to cosmopolitan, global is just the spatial scope of an actor. For example the United Nations (UN) has a global scope while the mayor of Paris has a local scope. Dependent on the question the researchers can divide the y-axis continuum in several scopes such as subnational, national or regional.

As I mentioned in the introduction, the opposite of cosmopolitanism is highly contested. Chris Brown (1992) proposes the distinction of cosmopolitanism and communitarism and Michael Zürn expands this into a broader concept for international political theory and the politicization of world politics (2014). The main aspect of communitarism seems to be an account of limited communities which are not open for foreigners. However such a concern is also possible in liberal theories. John Rawls for example is not a cosmopolitan thinker (see the criticism by Benhabib 2009, 79-88), but he is not a communitarian either. Nevertheless, Rawls argues for fixed and limited communities - nations respectively nation-states - he does not see individuals as political actors on an international level and has a concept of international relations based on (neo-) realism (Rawls 2010).

Because of the theoretical ambiguity I reject the distinction of cosmopolitanism and communitarism and follow the approach by Broszies and Hahn (2010). Their distinction of cosmopolitanism and particularism bears the opportunity to subsume different - liberal and communitarian - approaches under the opposite of cosmopolitanism. The authors define

\footnotetext{
${ }^{88}$ In a later article Pichler confirms his findings by using data from the World Value Survey (Pichler 2012).
} 
particularism in three aspects: the overlapping of national sovereignty and justice, the realization of justice only for the members of a nation-state and the impossibility of a roughly similar global political structure with the same justice capacities as a nation-state (Broszies and Hahn 2010, 1112).

Therefore I propose the $\mathrm{x}$-axis as a continuum between cosmopolitanism and particularism. It is a continuum because I argue for an empirical grounding of the distinction in the cleavage theory and thus I see in cosmopolitanism vs. particularism a new international conflict line ${ }^{89}$. The research group headed by Hanspeter Kriesi (2008) describes two issues which do not fit in the existing cleavage theory: the issue of EU-integration and the issue of immigration and integration. They draw the conclusion that there is a new conflict line which they call it integration vs. demarcation. This conflict line will be the empirical base for the theoretical distinction of cosmopolitanism vs. particularism.

A cosmopolitan approach sees all people as human beings with the same 'right to have rights' (Arendt), argues for national borders as open as possible and the recognition of individuals as equal and reciprocal components of a public discourse. That is why cosmopolitanism has an integrated standpoint. On the other hand, a particularistic approach argues for limited access of foreigners to the existing national community, the realization of profound justice principles in the nation-state only and sees nation-states as the main actors on the international level. Thus particularism has a demarcated standpoint. For an empirical analysis the scope of integrate, less integrated, neutral, less demarcated and demarcated ${ }^{90}$ could be added. The following figure illustrates my considerations.

Figure 1: social science model for cosmopolitanism and particularism

\begin{tabular}{|l|l|}
\hline Particularism & \\
\hline & Local \\
\hline & Global \\
\hline & Cosmopolitanism \\
\hline
\end{tabular}

Source: Author.

\footnotetext{
${ }^{89}$ In his latest article Michael Zürn (2014) argues in the same way but on the theoretical base of cosmopolitanism and communitarism. As I already mentioned this theoretical distinction is inadequate.

90 This scale is based on the considerations of the bridging project "The Political Sociology of Cosmopolitanism and Communitarism" in the Social Science Research Center Berlin (WZB).
} 
In addition I propose that this model can be used to measure claims by political actors in the public sphere, because results from surveys contain the problem of the "sunshine-effect" societally accepted answers expressed by the respondents during a survey - and the related problem of abstract questions on issues and decisions without a concrete event. The public, however, is strongly affected by events on different issues and through the media political actors such as politicians or NGO's claim their positions, justify their actions and react on events. Focusing on events also has the advantage that researchers can compare the results over time and can examine different event structures and different levels of participation of political actors. A public debate on a new national immigration law has surely different actors and structure as a public dispute on the violation of human rights in the refugee camps in Greece or Italy.

\section{Conclusion}

Edgar Grande states that governance seems to be the "all-purpose-tool" in political science (Grande 2012, 565) and it can be added that for International Relation it is Global Governance. The main problem is that governance approaches are too focused on the efficient regulation and problem-solving through institutions. The result is that this concept is blind for power structures and different interests; it has a hidden normative base and does not recognize non-institutional actors enough. Critics of the governance approach try to focus on this term in a critical way and see transformations of the state and fundamental changes on the international level in governance structures.

After my considerations about governance research and its critics in chapter two, I proposed a theoretical approach of cosmopolitanism which can be used as an alternative to the governance paradigm. Thus, I presented the federal cosmopolitanism by Seyla Benhabib and explained her ideas of an equal and reciprocal 'public discourse' through deliberations, the change from national to cosmopolitan law and the understanding of 'democratic iterations' as transformations of the meaning of norms through public discourses. Although Benhabib's theoretical considerations are very elaborate, the localization of cosmopolitan norms on the local, national and global level is difficult and her empirical investigation of cosmopolitanism is insufficient.

Therefore and considering some of the first empirical findings on cosmopolitanism, I propose a two-axes-model which is theoretically derived. Moreover it does not equate the distinction between local and global with the distinction communitarism and cosmopolitanism. Since local and global do not exclude each other, I compose the y-axis of my model. For the xaxis I draw on both, the opposite pair of cosmopolitanism and particularism, and new insights 
on the cleavage integration vs. demarcation. Furthermore my cosmopolitan model is actorcentric which has the advantage that the convictions of human rights and international norms are connected with concrete actors and their position; without only focusing on international institutions and their regulation efficiency as the global governance approaches propose.

The next step for an empirical cosmopolitan research agenda is the usage of the model and the comparison of the normative considerations and the empirical findings, because, as Bernhard Peters $(2000,279)$ states, "the power of persuasion of universal principles has to show the plausibility of the concrete application". A normative theory cannot be disproved by empirical results, but the results can help the theory to focus. Moreover, empirical findings can illuminate possible blind spots in the (normative) theory. If the theory of cosmopolitanism and empirical results of cosmopolitan claims by political actors enter into a dialogue with the institutional focus of governance approaches, their combination produces a more complex view on international arrangements and the power of international norms. 


\section{References}

Archibugi, Daniele. 2003. "Cosmopolitical Democracy." In Debating Cosmopolitics, edited by Daniele Archibugi, 1-15. London, New York: Verso.

Benhabib, Seyla, edited. 2011a. Dignity in Adversity. Human Rights in Troubled Times. Cambridge: Polity.

Benhabib, Seyla. 2011b. "Introduction: Cosmopolitanism without illusions". In Dignity in Adversity. Human Rights in Troubled Times edited by Seyla Benhabib, 1-19. Cambridge: Polity.

Benhabib, Seyla. 2011c. "Twilight of sovereignty or the emergence of cosmopolitan norms? Rethinking citizenship in volatile times". In Dignity in Adversity. Human Rights in Troubled Times edited by Seyla Benhabib, 94-116. Cambridge: Polity.

Benhabib, Seyla. 2009 [2004]. Die Rechte der Anderen. Ausländer, Migranten, Bürger. Bonn: Bundeszentrale für politische Bildung.

Benhabib, Seyla. edited. 2006a. Another Cosmopolitanism. Oxford: Oxford Univ. Press.

Benhabib, Seyla. 2006b. “The Philosophical Foundations of Cosmopolitan Norms”. In Another Cosmopolitanism, edited by Seyla Benhabib, 13-44. Oxford: Oxford Univ. Press.

Benhabib, Seyla. 2006c. "Democratic Iterations: The Local, the National, and the Global". In Another Cosmopolitanism, edited by Seyla Benhabib, 45-80. Oxford: Oxford Univ. Press..

Benz, Arthur. 2004. „Einleitung: Governance - Modebegriff oder nützliches sozialwissenschaftliches Konzept?“ In Governance - Regiergen in komplexen Regelsystemen. Eine Einführung, edited by Arthur Benz, 11-28. Wiesbaden: VS Verlag.

Brand, Ulrich. 2011a. „Global Governance als ordnungswissenschaftliches Konzept (zwischen)staatlichen Regierens im globalisierten Kapitalismus - und alternative Vorstellungen“. In Demokratie und Governance. Kritischen Perspektiven auf neue Formen politischer Herrschaft, edited by Alex Demirovic and Heide Walk, 257-278. Münster: Westfälisches Dampfboot.

Brand, Ulrich. 2007. „Zwischen Normativität, Analyse und Kritik. Die jüngere Diskussion um Global Governance.“ Journal für Entwicklungspolitik 23 (1): 26-50.

Brand, Ulrich. 2005. "Order and regulation: Global Governance as a hegemonic discourse of international politics?” Review of International Political Economy 12 (1): 155-176.

Broszies, Christoph, and Henning Hahn. 2010. "Die Kosmopolitismus-Partikularismus-Debatte im Kontext." In Globale Gerechtigkeit. Schlüsseltexte zur Debatte zwischen Partikularismus und Kosmopolitismus, edited by Christoph Broszies and Henning Hahn, 9-51. Frankfurt a. M.: Suhrkamp.

Brown, Chris. 1992. International Relations Theory. New Normative Approaches. New York: Columbia University Press. 
Delanty, Gerard. 2012. "Introduction: the emerging field of cosmopolitanism studies." In: Routledge Handbook of Cosmopolitanism Studies, edited by Gerard Delanty, 1-8. Routledge: Abingdon.

Dingwerth, Klaus, and Philipp Pattberg. 2006. „Was ist Global Governance.“ Leviathan 34 (3): 377-399.

Enderlein, Henrik, Sonja Wälti, and Michael Zürn. edited. 2010. Handbook on Multi-Level Governance. Cheltenham: Elgar.

Grande, Edgar 2012. „Governance-Forschung in der Governance-Falle? - Eine kritische Bestandsaufnahme.“ Politische Vierteljahresschrift (PVS) 53 (4): 565-592.

Habermas, Jürgen. 1998a. Faktizität und Geltung. Beiträge zur Diskurstheorie des Rechts und des demokratischen Rechtsstaates. Reprint of the 4. edition and extended to a postscript and bibliography. Frankfurt a. M.: Suhrkamp.

Habermas, Jürgen. 1998b. „Die postnationale Konstellation und die Zukunft der Demokratie.“ In Die postnationale Konstellation, edited by Jürgen Habermas, 91-169. Frankfurt a. M.: Suhrkamp.

Hannerz, Ulf. 1990. "Cosmopolitans and Locals in World Culture." Theory Culture Society 7 (2): 237-251.

Held, David. 1997. Democracy and the Global Order. From the Modern State to Cosmopolitan Governance. Cambridge: Polity Press.

Kacowicz, Arie M. 2012. "Global Governance, International Order, and World Order." In Oxford Handbook of Governance, edited by David Levi-Faur, 686-698. Oxford: Oxford Univ. Press.

Kriesi, Hanspeter, Edgar Grande, Romain Lachat, Martin Dolezal, Simon Bornschier, and Timotheos Frey. 2008. West European Politics in the Age of Globalization. Cambridge: Cambridge Univ. Press.

Levi-Faur, David. edited. 2012. Oxford Handbook of Governance. Oxford: Oxford Univ. Press.

Offe, Claus. 2009. “Governance: An ,Empty Signifier??” Constellations 16 (4): 550-562.

Olofsson, Anna, and Susanna Öhman. 2007. "Cosmopolitans and Locals: An Empircical Investigation of Transnationalism.” Current Sociology 55 (6): 877-895.

Peters, Bernhard. 2000. „Normative Theorien und soziale Empirie.“ In Das Interesse der Vernunft. Rückblicke auf das Werk von Jürgen Habermas seit „Erkenntnis und Interesse“, edited by Stefan Müller-Doohm, 274-298. Frankfurt a. M.: Suhrkamp.

Pichler, Florian. 2012. "Cosmopolitanism in a global perspective: An international comparison of open-minded orientations and identity in relation to globalization." International Sociology 27 (1): $21-50$. 
Pichler, Florian. 2009. "'Down-to-Earth' Cosmopolitanism: Subjective and Objective Measurements of Cosmopolitanism in Survey Research.” Current Sociology 57 (5): 704-732.

Rawls, John. 2010. „Das Völkerrecht.“ In: Globale Gerechtigkeit. Schlüsseltexte zur Debatte zwischen Partikularismus und Kosmopolitismus, edited by Christoph Broszies and Henning Hahn, 55-103. Frankfurt a. M.: Suhrkamp.

Risse, Thomas. 2012. "Governance in Areas of Limited Statehood." In Oxford Handbook of Governance, edited by David Levi-Faur, David, 699-715. Oxford: Oxford Univ. Press.

Roudometof, Victor. 2012. "Cosmopolitanism and empirical social research. Some methodological issues of an emerging research agenda." In Routledge Handbook of Cosmopolitanism Studies, edited by Gerard Delanty, 115-126. Abingdon: Routledge.

Roudometof, Victor. 2005. "Transnationalism, Cosmopolitanism and Glocalization." Current Sociology 53 (1): 113-135.

Schuppert, Gunnar Folke. 2008. „Governance - auf der Suche nach Konturen eines ,anerkannt uneindeutigen Begriffs“". In Governance in einer sich wandelnden Welt. PVS Sonderheft 41, edited by Gunnar Folke Schuppert, and Michael Zürn, 13-40. Wiesbaden: VS Verlag.

Schuppert, Gunnar Folke, and Michael Zürn. edited. 2008. Governance in einer sich wandelnden Welt. PVS Sonderheft 41. Wiesbaden: VS Verlag.

Senghaas, Dieter. 2003. „Die Konstitution der Welt - eine Analyse in friedenspolitischer Absicht.“ Leviathan 31 (1): 117-152.

Zürn, Michael. 2014. "The politicization of world politics and its effects: Eight propositions." European Political Science Review 6 (1): 47-71. 